\title{
DAMPAK SOSIAL EKONOMI RELOKASI PEDAGANG KAKI LIMA DI KECAMATAN BUDURAN KABUPATEN SIDOARJO
}

\author{
Mochammad Aringga Prasetya \\ Luluk Fauziah \\ (Prodi Ilmu Administrasi Negara - FISIP Universitas Muhammadiyah Sidoarjo \\ Jalan Majapahit 666 B Sidoarjo \\ email: aringga10@gmail.com, lulukfauz@yahoo.co.id)
}

\begin{abstract}
ABSTRAK
Tujuan penelitian ini adalah untuk mendeskripsikan proses relokasi PKL, dampak sosial ekonomi relokasi PKL, faktor pendukung dan penghambat relokasi PKL di kawasan jembatan layang Kecamatan Buduran Kabupaten Sidoarjo. Metode yang digunakan adalah deskriptif kualitatif. Informan kunci dalam penelitian ini adalah staf bidang perdagangan Dinas Koperasi, UKM, Perindustrian dan Perdagangan Kabupaten Sidoarjo. Dengan teknik pengumpulan data melalui wawancara, observasi dan dokumentasi selanjutnya dianalisis melalui tahap pengumpulan data, reduksi data, penyajian data dan penarikan kesimpulan. Hasil penelitian menunjukkan bahwa proses relokasi PKL tidak sesuai dengan tahapan relokasi yang tertuang dalam Peraturan Dalam Negeri Nomor 41 Tahun 2012 yang dimulai dari tahap pendataan dengan dua kali survei dan pendaftran PKL, penetapan lokasi PKL, pemindahan dan penghapusan lokasi PKL, sampai peremajaan lokasi PKL. Relokasi tersebut akhirnya dilakukan oleh Dinas Kebersihan dan Pertamanan Kabupaten Sidoarjo yang mengambil langkah diskresi atas kebijakan tersebut. Dampak sosial relokasi PKL di kawasan jembatan layang Kecamatan Buduran, dari segi kenyamanan PKL lebih merasa nyaman. Tetapi dalam segi keamanan masih belum sepenuhnya terjaga. Pendapatan PKL mayoritas menurun karena belum adanya pemberdayaan dari pemerintah. Pemerintah juga mempunyai kendala dalam merelokasi PKL karena terbatasnya lahan yang ada serta mindset PKL yang masih nyaman berjualan di bahu jalan karena tidak ada uang sewa tempat.
\end{abstract}

Kata kunci: dampak sosial ekonomi, relokasi, pedagang kaki lima 


\title{
SOCIO-ECONOMIC IMPACT OF RELOCATION TRADERS FIVE FEET IN THE DISTRICT BUDURAN SIDOARJO
}

\begin{abstract}
The purpose of this study was to describe the process of relocating street vendors, socio-economic impacts of the relocation of street vendors, enabling and inhibiting factors in the relocation of street vendors Buduran Sidoarjo District flyover. The method used is descriptive qualitative. The key informants in this study is a cooperative trade field staff, SMEs, Trade and Industry Sidoarjo. With the technique of collecting data through interviews, observation and documentation and then analyzed through the stages of data collection, data reduction, data presentation and conclusion. The results showed that the process of relocating street vendors are not in accordance with the stages of the relocation as stipulated in the Regulation of Home Affairs Number 41 Year 2012 which begins from the stage of data collection by the two surveys and registration of street vendors, determining the location of street vendors, transfer and removal of the location of street vendors, for the rejuvenation of the location of street vendors. Relocation was finally done by the Department of Hygiene and Sidoarjo Regency which take discretionary acts such policies. The social impact of the relocation of street vendors in the area overpass Buduran district, in terms of comfort PKL more comfortable. But in terms of security is still not fully awake. PKL majority income declined due to the lack of empowerment of government. The government also has obstacles in the relocation of street vendors because of the limited land available as well as street vendors mindset still comfortable selling on the shoulder of the road because there is no money to rent a place.
\end{abstract}

Keywords: socio-economic impacts, relocation, street vendors

\section{PENDAHULUAN}

Kota-kota besar di Indonesia sedang melakukan pembangunan dalam rangka meningkatkan taraf hidup kesejahteraan masyarakat yang lebih baik, namun pembangunan yang terpusat di perkotaan menyebabkan pembangunan di pedesaan tertinggal baik dari segi ilmu pengetahuan, sosial maupun ekonomi. Pembangunan kota yang pesat tidak diimbangi oleh lapangan kerja mengakibatkan pengangguran apalagi tidak didukung dengan SDM yang memadai, akhirnya mereka memilih pekerjaan di bidang sektor informal. 
Usaha PKL dalam memajukan usahanya terlihat jelas dengan kegigihan mereka dalam mengembangkan usahanya. Jenis usaha PKL yang tergolong dalam jenis usaha kecil sebagaimana dijelaskan dalam Undang-Undang Nomor 20 Tahun 2008 Tentang Usaha Kecil seharusnya bisa lebih berkembang dengan tidak mengganggu kelangsungan kegiatan publik. Pada kenyataannya, keberadaan PKL di kota-kota besar menimbulkan masalah baik bagi pemeritah setempat maupun pengguna jalan karena semakin melebarnya PKL menjajakan dagangannya. Menurut Ketua Asosiasi PKL Indonesia (APKLI) tahun 2012 mengatakan bahwa jumlah PKL mengalami kenaikan yang mencapai 9,8 juta atau naik $42 \%$ dari total 23,4 juta PKL di seluruh wilayah perkotaan Indonesia (Tempo, 5 September 2012). Sementara itu menurut Kepala Dinas UKM Jawa Timur, berupaya menciptakan lingkungan kondusif bagi lokasi PKL dengan membuat klaster PKL Kabupaten/Kota di Jawa Timur (Kabar Bangkalan, 8 September 2015).

Relokasi PKL bertujuan agar terciptanya keindahan tata ruang Kota dan kelancaran proses pelaksanaan pembangunan di wilayah perkotaan. Selain itu, hal tersebut merupakan upaya pemerintah Kabupaten Sidoarjo agar ruang terbuka hijau di kawasan jembatan layang tetap bersih, rapi, tidak kumuh, tertib dan nyaman sehingga tidak mengganggu pengguna jalan. Namun, relokasi yang sudah dilakukan oleh Pemkab Sidoarjo tidak sesuai dengan regulasi kebijakan yakni Peraturan Daerah Kabupaten Sidoarjo Nomor 10 Tahun 2013 Tentang Ketertiban Umum dan Ketentraman Masyarakat yaitu melarang setiap orang/badan berjualan di bahu jalan, trotoar dan taman selain peruntukkannya. Merelokasi PKL ke tempat baru sering dilakukan oleh pemerintah namun, keputusan relokasi seringkali sepihak. Sehingga pendapatan PKL merosot dan menimbulkan permasalahan yang baru. Akibatnya PKL kembali ke tempat semula atau mencari lokasi lain yang lebih menjanjikan.

Kabupaten Sidoarjo sebagai salah satu kota UKM di Indonesia yang tumbuh dan berkembang bersama dengan pelaku bisnis sektor informal. Menurut Kepala Diskoperindag ESDM Sidoarjo (2015), mengatakan jumlah PKL di Kota Delta mencapai 4.188 orang. Kecamatan Buduran mempunyai 190 PKL yang sudah terdaftar di Dinas Koperasi, UKM, Perindustrian, Perdagangan dan ESDM Kabupaten Sidoarjo dari jumah keseluruhan PKL yang terdaftar di Kabupaten Sidoarjo. PKL paling banyak berada di Kecamatan Candi dengan jumlah 865 PKL, sedangkan yang paling sedikit ada di Kecamatan Jabon dengan jumlah 76 PKL. Ini menunjukkan betapa menjamurnya PKL yang berada di Kabupaten Sidoarjo. Dampaknya PKL menjadi tidak terkontrol keberadaanya karena kurangnya tempat atau lokasi untuk menampung PKL di Kabupaten Sidoarjo.

Berdasarkan observasi, PKL yang berada di kawasan jembatan layang kecamatan Buduran menggunakan bahu jalan untuk berdagang sehingga 
mengganggu pengguna jalan yang melintas di jalan tersebut, sehingga sering tejadi macet di ruas jalan. Selain itu tempat berjualan PKL juga merusak estetika keindahan ruang terbuka hijau dan membuat lingkungan sekitar menjadi kumuh. Selain itu, tidak semua PKL yang berada di kawasan jembatan layang Kecamatan Buduran Kabupaten Sidoarjo bisa direlokasi. Sementara itu relokasi ini diharapkan dapat meningkatkan kualitas pelayanan dan daya tampung pedagang serta pembeli dalam mengembangkan usahanya dan meningkatkan kesejahteraan PKL sebagaimana yang sudah diatur dalam Peraturan Daerah Nomor 23 tahun 2014 tentang penataan dan pemberdayaan PKL. Dari uraian latar belakang diatas, rumusan masalah dalam penelitian antara lain bagaimanakah proses relokasi PKL di kawasan jembatan layang Kecamatan Buduran Kabupaten Sidoarjo, bagaimanakah dampak sosial ekonomi PKL setelah relokasi di kawasan jembatan layang Kecamatan Buduran Kabupaten Sidoarjo, dan apa sajakah faktor pendukung dan penghambat relokasi PKL. Sedangkan, tujuan penelitian ini adalah untuk mendeskripsikan proses relokasi PKL di kawasan jembatan layang Kecamatan Buduran Kabupaten Sidoarjo, mendeskripsikan dampak sosial ekonomi PKL setelah relokasi di kawasan jembatan layang Kecamatan Buduran Kabupaten Sidoarjo, serta untuk mendeskripsikan faktor pendukung dan faktor penghambat dalam relokasi PKL.

\section{LANDASAN TEORETIS}

\section{Perubahan Sosial}

Menurut Wilbert E. Moore dalam Soekanto (1983:6), perubahan sosial merupakan perubahan yang terjadi pada sistem sosial termasuk didalamnya interaksi antar aktor serta aturan atau norma yang berlaku. Oleh sebab itu, dalam menganalisa perubahan sosial ada tiga hal penting yang harus diamati, yaitu perubahan struktur sosial, pola-pola perilaku, dan sistem interaksi sosial, termasuk perubahan norma, nilai, dan fenomena kultural yang ada dalam lingkungan masyarakat. Sebagaimana yang dijelaskan oleh Moore dalam Soekanto (1983:232-233) bahwa perubahan-perubahan yang terjadi di dalam masyarakat terikat oleh ruang dan waktu, tetapi karena sifatnya yang berantai, maka keadaan tersebut berlangsung secara terus menerus, meskipun terkadang diselingi oleh keadaan-keadaan dimana masyarakat yang bersangkutan mengadakan reorganisasi unsur-unsur struktur masyarakat yang terkena oleh proses perubahan tersebut.

Perubahan sosial dalam pemberdayaan komunitas pada hakekatnya merupakan suatu proses perubahan evolusioner yang disengaja (intended change) 
dan terarah (directional change). Unsur-unsur yang terkandung dalam suatu perubahan sosial dirumuskan oleh Kotler (1978:29-33) sebagai "5C”, yaitu :

a) Cause (sebab), yaitu upaya atau tujuan sosial yang dipercaya oleh pelaku perubahan dapat memberikan jawaban pada masalah sosial.

b) Change agency (agen perubahan), yaitu organisasi yang misi utamanya memajukan upaya perubahan sosial.

c) Change target (sasaran perubahan), yaitu individu atau kelompok sosial yang ditunjuk sebagai sasaran upaya perubahan.

d) Channel (saluran), yaitu media untuk menyampaikan pengaruh dan respon dari setiap pelaku perubahan ke sasaran perubahan.

e) Change strategy (strategi perubahan), yaitu teknik utama mempengaruhi yang diterapkan oleh pelaku perubahan untuk menimbulkan dampak pada sasaran perubahan.

Sedangkan Kotler (1978:18) mengemukakan bahwa upaya perubahan sosial (social change) yang terarah dalam pemberdayaan komunitas tidak lepas kaitannya dengan masalah sosial (social problem) dan aksi sosial (social action). Tiga hal tersebut merupakan satu rangkaian yang saling berhubungan. Adanya masalah sosial dapat menimbulkan perubahan sosial dan untuk mengarahkannya diperlukan aksi sosial. Selanjutnya peneliti menggunakan teori dampak sosial ekonomi sampai dengan konsep penataan pedagang kaki lima sebagai acuan untuk menganalisis permasalahan yang terjadi di dalam penelitian ini.

\section{Dampak Sosial Ekonomi}

Dampak sosial ekonomi dapat dilihat dari sisi positif dan negatif sehingga dapat lebih berimbang dalam memberikan penilaian. Beberapa hal yang bersifat positif yaitu meningkatnya kelayakan dan kenyamanan usaha, terbukanya kesempatan kerja, perubahan status menjadi pedagang legal. Dampak negatif yaitu menurunnya pendapatan, meningkatnya biaya operasional, melemahnya jaringan sosial, dan menurunnya kesempatan pedagang untuk ikut dalam kelompokkelompok sosial non formal (Sinaga, 2004:134). Sedangkan menurut Djojodipuro (1992:194), dampak sosial ekonomi merupakan perubahan yang terjadi pada masyarakat yang diakibatkan adanya aktivitas pembangunan yang berpengaruh terhadap perubahan pendapatan, kesempatan berusaha, dan penyerapan tenaga kerja. Dampak sosial ekonomi ini terjadi pada sistem ekonomi yang menyangkut struktur dan kondisi ekonomi. Sehingga didapat konsep pola penataannya yang diadaptasi dari konsep Sutrisno, et.al (2007:170) dapat digambarkan dalam tabel berikut: 
Tabel 2.

Konsep Pola Penataan PKL Berdasar Tinjauan Aspek Sosial dan Ekonomi

\begin{tabular}{|c|c|}
\hline Konsep & Indikator \\
\hline \multicolumn{2}{|c|}{ Aspek Sosial } \\
\hline $\begin{array}{l}\text { 1. Penyuluhan tentang waktu usaha, } \\
\text { tempat usaha dan sarana usaha yang } \\
\text { menjamin keindahan dan keamanan } \\
\text { yang mendukung program Pemkab. } \\
\text { 2. Penyuluhan sadar hukum sebagai } \\
\text { pembinaan non fisik, agar PKL } \\
\text { dapat menjalin hubungan serasi } \\
\text { dengan lingkungan tempat usaha } \\
\text { dengan prinsip tidak ada yang } \\
\text { merasa dirugikan. }\end{array}$ & $\begin{array}{l}\text { 1. Adanya penyuluhan tentang waktu } \\
\text { usaha, dan tempat usaha, sarana } \\
\text { usaha }\end{array}$ \\
\hline $\begin{array}{l}\text { 1. Penyuluhan sadar hukum sebagai } \\
\text { pembinaan non fisik agar PKL } \\
\text { bertanggungjawab terhadap } \\
\text { ketertiban kerapian, kebersihan, } \\
\text { keindahan, kesehatan lingkungan } \\
\text { dan keamanan di sekitar tempat } \\
\text { usaha } \\
\text { 2. Pengaturan tempat usaha PKL yang } \\
\text { menjamin ketertiban, keamanan dan } \\
\text { keindahan kota, serta menunjang } \\
\text { program pemerintah menjadikan } \\
\text { kota sebagai kota budaya, pariwisata } \\
\text { dan olahraga. }\end{array}$ & $\begin{array}{l}\text { 1. Adanya penyuluhan non fisik dan } \\
\text { pengaturan tentang bertanggung } \\
\text { jawab atas ketertiban, kerapian, } \\
\text { kebersihan, keindahan, kesehatan } \\
\text { lingkungan, dan keamanan tempat } \\
\text { usaha. }\end{array}$ \\
\hline \multicolumn{2}{|c|}{$\begin{array}{c}\text { Aspek Ekonomi } \\
\end{array}$} \\
\hline $\begin{array}{l}\text { 1. Memberdayakan usaha sektor } \\
\text { informal PKL dengan jaminan } \\
\text { perlindungan, pembinaan dan } \\
\text { pengaturan usaha agar lebih berdaya } \\
\text { guna dan berhasil guna serta dapat } \\
\text { meningkatkan kesejahteraan PKL } \\
\text { khususnya dan masyarakat kota } \\
\text { umumnya. }\end{array}$ & $\begin{array}{l}\text { 1. Adanya jaminan perlindungan bagi } \\
\text { PKL } \\
\text { 2. Adanya pembinaan PKL }\end{array}$ \\
\hline $\begin{array}{l}\text { 1. Pemkot beserta seluruh elemen } \\
\text { masyarakat mendukung usaha PKL } \\
\text { dengan menciptakan kondisi yang } \\
\text { kondusif dan melakukan pembinaan } \\
\text { dan upaya mengembangkan } \\
\text { kemampuan manajerial, agar usaha } \\
\text { PKL lebih berkembang. }\end{array}$ & $\begin{array}{l}\text { 2. Kondisi yang kondusif oleh seluruh } \\
\text { elemen masyarakat } \\
\text { 3. Adanya pengembangan kemampuan } \\
\text { manajerial PKL yang baik }\end{array}$ \\
\hline
\end{tabular}




\begin{tabular}{|l|lr|l|}
\hline 1. Pemkot beserta stakeholders kota & 1. Adanya kerjasama permodalan \\
menjalin kerjasama dalam & 2. Adanya kerjasama kemitraan \\
permodalan dan kemitraan & usaha & pemerintah dan stakeholder dengan \\
dengan PKL yang saling & PKL \\
menguntungkan kedua belah pihak. &
\end{tabular}

Sumber : Sutrisno, et.al (2007:171)

\section{Relokasi}

Menurut Binsar M. Gulton dalam Lusiani (2008:14) mengatakan bahwa secara umum pengertian relokasi sering dimaknai sekedar sebagai pemindahan tempat dari segi ruang geografis. Padahal tidak dapat dipungkiri bahwa relokasi menyangkut pertarungan antar berbagai konsep ruang seperti ruang ekonomi, sosial, politik, lingkungan hidup hingga ke ruang budaya. Sedangkan Menurut F. Davidson dalam Lusiani (2008:14) mengatakan bahwa lokasi dan kualitas tempat relokasi baru adalah faktor penting dalam perencanaan relokasi, karena sangat menentukan hal-hal seperti kemudahan menuju ke lahan usaha, jaringan sosial, pekerjaan, bidang usaha, kredit dan peluang pasar. Setiap lokasi mempunyai keterbatasan dan peluang masing-masing. Memilih lokasi yang sama baik dengan kawasan yang dahulu dari segi karakteristik lingkungan, sosial, budaya dan ekonomi akan lebih memungkinkan relokasi dan pemulihan pendapatan berhasil.

\section{METODE PENELITIAN}

Tipe penelitian kualitatif deskriptif ini menggambarkan fenomena dan fakta yang terjadi dalam dampak sosial relokasi PKL. Teknik pengumpulan data dilakukan dengan cara observasi, wawancara dan dokumentasi (Sugiyono, 2011:224). Informan peneltian ini berjumlah sembilan orang. Analisis data dalam penelitian ini terdapat empat alur kegiatan yang terjadi secara bersamaan, yaitu data yang telah terkumpul dibaca, dipelajari dan dirangkum. Setelah dilakukan reduksi data disajikan dalam bentuk uraian singkat, bagan, dan teks naratif. Selanjutnya dilakukan penarikan kesimpulan yang didukung bukti valid dan konsisten.

\section{HASIL DAN PEMBAHASAN}

\section{Proses Relokasi PKL di kawasan jembatan layang Kecamatan Buduran Kabupaten Sidoarjo}

Sosialisasi kebijakan penataan dan pemberdayaan di Kabupaten Sidoarjo dimaksudkan sebagai langkah penyebarluasan informasi utamanya kebijakan pemerintah terkait penanganan PKL di Kabupaten Sidoarjo kepada seluruh pemangku kepentingan utamanya kalangan birokrat sampai di tingkat wilayah. 
Hal tersebut bertujuan untuk memberikan kesempatan berusaha bagi PKL melalui penetapan lokasi sesuai dengan peruntukannya; menumbuhkan \& mengembangkan kemampuan usaha PKL menjadi usaha ekonomi mikro yang tangguh \& mandiri; untuk mewujudkan kota yang bersih, indah, tertib \& aman dengan sarana $\&$ prasarana perkotaan yang memadai \& berwawasan lingkungan. Sehingga penataan PKL memiliki beberapa tahapan/proses yang dilakukan sebelum PKL tersebut ditempatkan pada satu lokasi yang memang diperuntukkan untuk PKL.

Dinas Koperasi, UKM, Perindustrian, Perdagangan dan ESDM Kabupaten Sidoarjo mengeluarkan TDU bagi PKL Sebagai bentuk untuk melegalkan PKL. Tetapi, syarat untuk mendapatkan TDU adalah orang yang memiliki KTP Sidoarjo. Namun, PKL juga belum bisa mendapatkan TDU apabila lokasi belum ditetapkan sesuai dengan Surat Keputusan (SK) Bupati. Untuk PKL di kawasan jembatan layang Kecamatan Buduran itu adalah program dari Dinas Kebersihan dan Pertamanan dengan tujuan agar lebih tertata dan lebih rapi. Hal ini diperkuat oleh pernyataan Ibu (RN) selaku Staf Bidang Perdagangan di Dinas Koperasi, UKM, Perindustrian, Perdagangan dan ESDM Kabupaten Sidoarjo berikut ini:

"Jadi prosesnya di data dulu PKLnya untuk mendapatkan TDU, syaratnya harus memiliki KTP Sidoarjo. Tetapi, relokasi bisa dilakukan jika tempat sudah ditetapkan sesuai dengan SK Bupati, dan PKL belum bisa mendapatkan TDU jika lokasi belum ditetapkan......." (Hasil wawancara pada tanggal 18 April 2016).

Berdasarkan penjelasan di atas dapat diketahui bahwa relokasi PKL di kawasan jembatan layang Kecamatan Buduran Kabupaten Sidoarjo tidak melalui tahap proses relokasi sesuai dengan regulasi yang ditetapkan oleh Pemerintah. Karena relokasi tersebut merupakan program dari DKP Kabupaten Sidoarjo untuk menata PKL yang masih berjualan di bahu jalan dan trotoar ke dalam taman. Langkah tersebut memang diapresiasi dengan baik oleh tim kordinasi penataan dan pemberdayaan PKL Kabupaten Sidoarjo karena langkah tersebut dianggap sebagai langkah awal untuk mengatasi masalah PKL di kawasan jembatan layang Kecamatan Buduran Kabupaten Sidoarjo. Tetapi, fasilitas tempat berjualan PKL dirasa masih kurang baik bagi pembeli yang ingin singgah. Dalam temuan Heriyanto (2012) juga terungkap bahwa kendala yang dihadapi pedagang kaki lima adalah dari sisi infrastruktur dan fasilitas setelah mengalami relokasi, pemerintah sebagai pengelola diharapkan mampu memperbaiki kawasan pejalan kaki yang rusak dan memperluas ruang parkir. 


\section{Dampak Sosial Ekonomi Relokasi PKL}

\section{Dampak Sosial Relokasi PKL}

PKL yang dipindah ke suatu tempat/direlokasi pasti mempunyai banyak pertimbangan akan dampak yang bisa timbul dari perpindahan lokasi tersebut. Tentunya jika sesuai dengan prosedur dan alur yang benar, proses relokasi akan berdampak positif pada kegiatan PKL maupun pemerintah. Sebaliknya, apabila relokasi tersebut belum sesuai dengan prosedur dan aturan yang ada akan berdampak negatif pada kegiatan PKL maupun pemerintah. Jadi diperlukan adanya koordinasi antara pemerintah dan PKL dalam proses menentukan suatu lokasi PKL akan berpengaruh pada tingkat kenyamanan PKL dalam menjalankan usahanya.

Dalam segi kenyamanan memang PKL merasakan lebih enak dan nyaman berjualan di dalam taman dan disediakan shelter karena mereka tidak lagi mendorong/bongkar pasang gerobak jualan mereka lagi. Selain itu, paguyuban juga memberlakukan retribusi kebersihan bagi PKL yang berjualan sebesar Rp 3000,-/PKL. Sementara untuk juru parkir yang ada, bukan dikelola oleh paguyuban, tetapi ada pihak dari luar yang tanpa seijin ketua paguyuban langsung menjadi juru parkir di lokasi tersebut. Jadi dalam hal parkir, paguyuban tidak ikut mengelola parkir tersebut. Seperti yang diungkapkan Bapak (SS) ketua paguyuban taman patung Mangundiprojo berikut ini:

“...dari PKL sendiri ada retribusi kebersihan untuk kebutuhan paguyuban dan setor ke DKP yaitu Rp. 3000/hari. Parkir sudah disediakan memang. Tapi yang jadi jukir itu anak Desa Sono, itu ilegal juga, jadi orang PKL sudah tidak mau tahu. Kalau nyaman ya lebih enak disini, tidak usah nyurung rombong (bahasa Indonesia: dorong gerobak)......" (Hasil wawancara pada tanggal 17 April 2016)

Menurut hasil wawancara di atas dampak secara sosial relokasi tersebut dalam segi kenyamanan PKL merasa nyaman setelah dipindah. Relokasi di kawasan jembatan layang Kecamatan Buduran Kabupaten Sidoarjo memang dirasa lebih nyaman dan lebih aman berjualan di dalam taman. Karena sudah tidak takut lagi akan adanya penertiban dan tidak lagi bongkar pasang "rombong". Tetapi dampak negatifnya masyarakat tidak bisa menikmati fungsi taman sebagaimana mestinya yang biasanya dibuat jalan-jalan, santai dan menikmati udara segar taman. Selain itu, faktor kemanan akan berpengaruh pada kenyamanan pengunjung untuk singgah. Dalam hal kebersihan relokasi ke dalam taman memang terlihat lebih rapi, tetapi hak tersebut tidak menjamin PKL bisa 
ikut serta merawat taman tersebut sehingga dapat memberikan rasa nyaman bagi pengunjung dan PKL yang berjualan. Karena apabila kebersihan tidak terjaga dengan baik, bisa jadi lokasi tersebut akan sepi pembeli.

Dalam temuan Heriyanto (2012) juga terungkap bahwa relokasi yang dilakukan pemerintah harus mempertimbangkan dampak positif dan negatif dalam segi sosial. Karena faktor kenyamanan usaha sangat berpengaruh pada tingkat keamanan, ketertiban, kebersihan tempat jual beli PKL dan sampai meningkatnya pendapatan PKL. Sehingga stigma negatif yang melekat pada PKL dapat berubah dengan ikut menjaga tatanan kota. Seperti yang terungkap dalam temuan Rahman (2014) dengan adanya relokasi, pedagang beranggapan kegiatan yang dilakukan pedagang menjadi lebih tertib dan aman sehingga tidak mengganggu keindahan tatanan kota.

Relokasi kedalam taman tersebut juga diharapkan oleh pemerintah bahwa PKL mampu merawat dan menjaga tanaman yang ada di taman agar tidak rusak. Karena sejatinya taman harus kelihatan bersih, rapi, dan asri sehingga keindahan dan tatanan kota tidak terganggu. Meminjam istilah Sutrisno, et.al (2007:170) dalam konsep penataan PKL bahwa pengaturan tempat usaha PKL yang menjamin ketertiban, keamanan dan keindahan kota, serta menunjang program pemerintah menjadikan kota sebagai kota budaya, pariwisata dan olahraga.

\section{Dampak Ekonomi Relokasi PKL}

Dampak ekonomi dari relokasi di kawasan jembatan layang Kecamatan Buduran Kaupaten Sidoarjo yang saat ini bernama taman kuliner Mangundiprojo dilihat dari sisi pendapatan yang diperoleh pedagang sebelum dan sesudah adanya relokasi. Sehingga antara pedagang yang satu dengan lainnya memiliki motivasi yang sama untuk mencari nafkah dalam memenuhi kebutuhan sehari-hari. Dampak ekonomi akibat relokasi meliputi tingkat pendapatan, pengembangan usaha dan termasuk modal usaha PKL. Dalam segi pendapatan, setelah direlokasi pendapatan PKL yang mereka peroleh masih belum maksimal didapatkan dan mayoritas pendapatannya menurun. Berdasar istilah Djojodipuro (1992:194) dampak sosial ekonomi merupakan perubahan yang terjadi pada masyarakat yang diakibatkan adanya aktivitas pembangunan yang berpengaruh terhadap perubahan pendapatan.

Dari segi ekonomi tingkat perekonomian PKL setelah direlokasi lebih meningkat dibanding sebelumnya yang menempati bahu jalan dan trotoar. Untuk bantuan permodalan masih belum ada karena PKL kawasan jembatan layang Kecamatan Buduran masih belum mendaftar untuk mendapatkan Tanda Daftar Usaha (TDU). Karena lokasi tersebut juga belum ditetapkan, maka pemberdayaan untuk pegembangan usaha PKL juga belum maksimal. Seperti yang diungkapakan 
Ibu (RN) selaku staf bidang perdagangan Dinas Koperasi, UKM, Perindustrian, Perdagangan dan ESDM Kabupaten Sidoarjo berikut ini:

“......untuk segi ekonomi lebih meningkat ya karena lebih tertata. Kalau bantuan permodalan setiap tahun kita ada yaitu dana bergulir. Jadi permodalan usaha yang sasarannya adalah pelaku usaha syaratnya punya surat Tanda Daftar Usaha (TDU) tadi, dia juga punya tempat......(Hasil wawancara pada tanggal 18 April 2016)

Berdasarkan penjelasan di atas dapat diketahui bahwa relokasi seharusnya bisa memningkatkan pendapatan PKL, namun kondisi di lapangan pendapatan PKL menurun dibandingkan sebelum relokasi. Untuk bantuan modal usaha juga belum pernah didapatkan PKL, karena PKL tersebut belum legal dan terdaftar di Diskoperindag Kabupaten Sidoarjo. Padahal bantuan permodalan sangat diharapkan oleh PKL untuk mengembangkan usahanya dan kemampuan yang dimiliki untuk membuat sesuatu sehingga dapat memenuhi kebutuhan sehari-hari.

Dalam temuan Fatnawati (2013) juga dijelaskan bahwa dilihat dari segi ekonomi, maka jelas dengan pengelolaan yang baik serta penempatan yang tepat menjadikan keuntungan dari segi finansial terutama bagi para PKL sendiri dan umumnya masyarakat umum yang menggunakan jasa mereka. Penelitian Setyaningsih dan Susilo (2014) juga ditemukan bahwa pedagang mengalami peningkatan pendapatan setelah direlokasi. Berbeda dengan relokasi di taman kuliner Mangundiprojo yang mayoritas pendapatan PKL menurun hampir $20 \%$. Karena lokasi taman kuliner Mangundiprojo yang ditempati PKL saat ini memang belum ditetapkan sebagai lokasi PKL, sehingga pemberdayaan dari pemerintah belum bisa dilaksanakan dan diterima PKL guna meningkatkan kualitas dagangan PKL.

\section{Faktor Pendukung dan Penghambat Relokasi PKL}

Hasil penelitian mengenai relokasi PKL menunjukkan bahwa terdapat faktor pendukung dan penghambat dalam pelaksanaannya. Faktor pendukung dalam relokasi PKL di Kawasan jembatan layang Kecamatan Buduran Kabupaten Sidoarjo adalah sosialisasi akan kenyamanan, kemanan dan kebersihan lokasi PKL, tempat PKL menarik perhatian pengunjung, tersedianya fasilitas dan sarana prasarana secara gratis guna menunjang tingkat kenyamanan pengunjung, rumor akan ditertibkannya semua PKL yang berjualan dipinggir jalan, adanya pembinaan dari pemerintah sebagai tindak lanjut dari relokasi. Berikut penuturan 
salah satu informan terkait faktor pendukung relokasi PKL di kawasan jembtan layang Kecamatan Buduran Kabupaten Sidoarjo:

"Faktor pendukungnya ya tempat yang kita sediakan bisa lebih ramai dari tempat sebelumnya, bagaimana kita bisa menciptakan lokasi PKL itu menjadi menarik perhatian pengunjung." (Hasil wawancara pada tanggal 18 April 2016).

Salah satu faktor yang mendukung relokasi tersebut adalah dengan melakukan sosialisasi akan kenyamanan, kemanan dan kebersihan lokasi PKL. Dalam temuan Rahman (2014) dijelaskan bahwa dengan melakukan relokasi tidak akan mengalami penggusuran terus menerus, karena tempat yang mereka gunakan untuk kegiatan jual beli dianggap mengganggu keamanan, ketertiban, dan keindahan tatanan kota. Selain itu, tempat yang disediakan bisa menarik perhatian pengunjung untuk datang dan jarak lokasi lama dengan yang baru tidak terlalu jauh sehingga pelanggan PKL masih bisa tahu keberadaan mereka. Seperti dalam temuan Fatmawati (2013) bahwa dalam pemilihan lokasi PKL disini dipengaruhi oleh kemudahan pencapaian, kemudahan dilihat dan kemudahan hubungan dengan aktifitas formal. Sehingga memudahkan pelanggan untuk mengakses keberadaan dan waktu para PKL tersebut memulai menjajakan dagangannya.

Namun peneliti menemukan faktor penghambat dalam relokasi PKL seperti lahan belum tersedia untuk PKL, edukasi ke masyarakat untuk ikut serta menata kota masih minim, anggaran untuk relokasi PKL masih terbatas, belum ada solusi untuk relokasi PKL, dan mindset PKL yang sudah terlanjur nyaman berjualan di bahu jalan sehingga tidak mau dipindah. Berikut penuturan para narasumber mengenai salah satu faktor penghambat relokasi PKL di kawasan jembatan layang Kecamatan Buduran Kabupaten Sidoarjo:

"Edukasi ke masyarakat masih minim, karena keterlibatan masyarakat untuk menata kota yang bersih juga sangat besar. Masalah terbatas anggaran, dan lahannya dimana juga tidak ada, mindset PKL yang lebih nyaman jualan di jalan karena tidak bayar, tidak terbebani uang sewa." (Hasil wawancara pada tanggal 27 April 2016)

Sehingga dapat disimpulkan bahwa faktor penghambat dalam relokasi PKL terbatasanya lahan yang tersedia untuk merelokasi PKL. Hal ini dikarenakan terbatasnya anggaran dari pemerintah untuk merelokasi PKL. Sehingga 
mengakibatkan relokasi PKL yang dilakukan hanya sekedar memindahkan PKL saja, tanpa memikirkan dampak dalam aspek sosial maupun ekonomi.

Merelokasi PKL tidak semudah membalikkan telapak tangan karena PKL yang sudah terlanjur nyaman ditempat tersebut merupakan salah satu penghambat PKL tidak mau direlokasi. Meskipun lahan sudah disediakan oleh pemerintah, namun belum menjamin PKL mau direlokasi. Hal tersebut karena ketakutan PKL akan penurunan pendapatan. Rasa nyaman PKL yang berjualan di bahu jalan dan ramai pengunjung. Mindset PKL dan pembeli (masyarakat) yang ingin serba gratis dan praktis dalam menjalankan aktifitas jual beli menjadi penghambat Pemerintah melakukan relokasi.

\section{SIMPULAN DAN SARAN}

\section{Simpulan}

a. Proses relokasi di kawasan jembatan layang Kecamatan Buduran tidak sesuai dengan tahapan relokasi seperti yang tertuang di dalam Peraturan Dalam Negeri Nomor 41 Tahun 2012 yang dimulai dari tahap pendataan yang dilakukan dua kali survei dan pendaftaran PKL, penetapan lokasi PKL, pemindahan dan penghapusan lokasi PKL, sampai peremajaan lokasi PKL. Relokasi tersebut akhirnya dilakukan oleh Dinas Kebersihan dan Pertamanan Kabupaten Sidoarjo yang mengambil langkah diskresi atas kebijakan tersebut, dengan tujuan agar PKL lebih tertata dan rapi.

b. Dampak sosial relokasi PKL di kawasan jembatan layang Kecamatan Buduran dari segi kenyamanan yaitu PKL lebih merasa nyaman karena telah disediakan tempat secara gratis oleh pemerintah. Dalam segi keamanan masih belum sepenuhnya terjaga dan aman karena pembeli lebih memilih parkir di pinggir jalan. Dalam segi kebersihan masih terlihat kumuh karena lokasi yang ditempati PKL adalah taman. Sedangkan dampak ekonomi yang dirasakan oleh PKL di kawasan jembatan layang Kecamatan Buduran Kabupaten Sidoarjo dari segi pendapatan mayoritas menurun hampir $20 \%$. Untuk modal usaha juga belum pernah didapatkan oleh PKL bahkan belum ada tawaran dari Pemerintah Kabupaten Sidoarjo. Sedangkan untuk pengembangan usaha, pemberdayaaan masih belum bisa dilakukan Dinas Koperasi Usaha Kecil Menengah Perindustrian Perdagangan dan Energi Sumber Daya Mineral Kabupaten Sidoarjo dikarenakan lokasi tersebut milik pemda.

c. Faktor pendukung relokasi PKL di kawasan jembatan layang Kecamatan Buduran adalah tempat relokasi dibuat menarik perhatian pengunjung dan tidak jauh dari tempat yang lama. PKL mendapatkan fasilitas secara gratis 
atau tidak dibebani sewa tempat. Tersedianya parkir yang luas sehingga pembeli yang datang merasa aman untuk memarkir kendaraanya (tidak parkir di bahu jalan). Sedangkan faktro penghambat relokasi adalah lahan yang disediakan oleh pemerintah masih minim dan hampir tidak ada. Ini dikarenakan anggaran yang masih terbatas untuk membeli lahan, sehingga belum ada solusi untuk merelokasi PKL. PKL merasa takut jualannya sepi jika pindah ke tempat yang baru karena mindset PKL yang masih nyaman berjualan di bahu jalan karena tidak ada uang sewa tempat.

\section{Saran}

a. Merelokasi PKL harus sesuai dengan Peraturan yang sudah ditetapkan. Langkah diskresi hendaknya diambil apabila solusi untuk merelokasi PKL sudah tidak lagi didapatkan. Sehingga diharapkan relokasi yang dilakukan dapat berdampak postif dalam aspek sosial maupun ekonomi.

b. Relokasi yang dilakukan hendaknya tidak sekedar memindahkan ke lokasi yang baru dan hanya menyediakan shelter untuk berjualan. Tetapi fasilitas guna menarik perhatian pembeli sangat diperlukan seperti tenda untuk tempat duduk pembeli, perbaikan saluran air, dan pemavingan agar tidak becek saat hujan. PKL hendaknya mengikuti pelatihan-pelatihan yang dilakukan pemerintah guna meningkatkan kualitas dagangannya seperti kemasan yang dipakai untuk menyajikan atau membungkus dagangannya agar lebih menarik.

c. Diharapkan adanya perhatian yang lebih besar dari pemerintah untuk mengurangi atau bahkan menghilangkan faktor yang menghambat perkembangan usaha PKL di kawasan jembatan layang Kecamatan Buduran. Membeli lahan menjadi urutan pertama yang harus dilakukan Pemerintah agar PKL bisa tertata dan terbina dengan baik. Melakukan edukasi secara persusasif dan berkala kepada masyarakat maupun PKL sendiri agar tidak melakukan aktivitas jual beli di tempat yang dilarang oleh Peraturan. Pendataan dan pendaftaran PKL harus segera disosialisasikan dan persyaratan yang diperlukan untuk didistribusikan untuk melegalkan status PKL.

\section{DAFTAR PUSTAKA}

Djojodipuro, Marsudi. (1992). Teori Lokasi. Jakarta: Lembaga Penerbit Fakultas Ekonomi Universitas Indonesia.

Fatnawati, Nur. (2013). Dampak Relokasi Pedagang Kaki Lima Berdasarkan Peraturan Daerah Kota Surakarta Nomor 3 Tahun 2008 Tentang 
Pengelolaan Pedagang Kaki Lima Terhadap Usaha Pedagang Kaki Lima Di Surakarta. Semarang: Universitas Negeri Semarang

Heriyanto, Aji Wahyu. (2012). Dampak Sosial Ekonomi Relokasi Pedagang Kaki Lima Di Kawasan Simpang Lima Dan Jalan Pahlawan Kota Semarang. Semarang: Universitas Negeri Semarang.

Kotler, Philip, (1978). Creating Social Change. New York: Hold Rinehart and Winston Inc.

Lusiani. (2008). Pengaruh Relokasi Pasar Klithikan Terhadap Pendapatan Pedagang Kaki Lima. Skripsi. Yogyakarta: FISE Universitas Negeri Yogyakarta.

Peraturan Daerah Kabupaten Sidoarjo Nomor 10 Tahun 2013 Tentang Penyelenggaraan Ketentraman dan Ketertiban Umum di Wilayah Kabupaten Sidoarjo.

Peraturan Dalam Negeri Nomor 41 Tahun 2012 Tentang Pedoman dan Penataan dan Pemberdayaan Pedagang Kaki Lima.

Pujiantoro, Hadi. (2015). Potensi PKL Bisa Untungkan Daerah. (Online). http://korankabar.com/potensi-pkl-bisa-untungkan-daerah/ kabar bangkalan. Diakses pada 8 September 2015.

Rahman, Abdul. (2014). Dampak Relokasi Pedagang Kaki Lima (PKL) Pasar Jongkok ke MTC Giant Panam Terhadap Kehidupan Sosial Ekonomi Pedagang. Pekanbaru: Universitas Riau.

Setyaning, Ayu \& Susilo Y. Sri. (2014). Dampak Sosial Ekonomi Relokasi Pasar Satwa Kasus Pasar Satwa dan Tanaman Hias Yogyakarta (PASTY) Tahun 2010-2014”. Yogyakarta: Universitas Atma Jaya Yogyakarta.

Sugiyono. (2011). Metode Penelitian Kualitatif, Kuantitatif dan R\&D. Bandung: Alfabeta.

Soekanto, Soerjono. (1983). Teori Sosiologi tentang Perubahan Sosial. Surabaya: Ghalia Indonesia.

Sinaga, S. (2004). Dampak Sosial Kebijakan Pemda DKI Jakarta Tentang Relokasi Pedagang Kaki Lima di Lokasi Binaan Studi Kasus di Lokasi Binaan Paal Merah Jakarta Pusat. Jakarta: Universitas Indonesia.

Sutrisno, Budi, et al. (2007). Pola Penataan Pedagang Kaki Lima (PKL) di Kota Surakarta Berdasar Paduan Kepentingan PKL, Warga Masyarakat, dan Pemerintah Kota. Jurnal Penelitian Humaniora, Vol. 8, No. 2, 2007. Surakarta: Universitas Muhammadiyah 
Pangaribowo, Herka Yaris. (2012). Pasca-Lebaran, Pedagang Kaki Lima Naik 42 Persen. (online). Tempo terbit Rabu tanggal 5 September 2012. Diakses pada 18 Mei 2016.

Undang-Undang Republik Indonesia Nomor 20 tahun 2008 tentang Usaha Mikro, Kecil, dan Menengah. 